VOLODYMYR ROMANTSOV,

Mariupol State University (Ukraine)

e-mail: romantsov_v@ukr.net,ORCID 0000-0002-9019-4149

NATALIA ROMANTSOVA, Mariupol State University (Ukraine)

e-mail: romantsov_v@ukr.net, ORCID 0000-0001-5032-1097

\title{
THE MARIUPOL LOCAL PUBLIC UNIVERSITY DURING 1917-1920-s: HISTORICAL OVERVIEW IN THE CONTEXT OF MODERN METHODOLOGICAL APPROACHES
}

\begin{abstract}
The foundation and activity of the Mariupol Local Public University under the social processes of the Ukrainian Revolution during 1917-1919-s is highlighted in the paper on the base of the modern methodological approaches. The history of the educational institution is analyzed in the context of anthropological, social, cultural and interdisciplinary approaches. The issues of the Mariupol Local Public University's organization and principles of its activity are considered regarding the principles of microhistory in detail. The educational activity, personnel and university enrolment are presented. The attention was drawn to the activity of the Mariupol democratic community regarding university's establishment, to an impact of changing social processes that were in Ukraine in general and in Mariupol in particular, according to the methodological principles of socio-cultural history. The role of the particular historical and public figures (namely, the head of the Board of trustees of the public university S. Vainerova, the heads of the City Council of Mariupol I. Popov and O. Levytskyi, the member of Mariupol public executive committee I. Kovalenko and others) is considered on the methodological bases of historical anthropology. The elements of history, social and cultural studies are combined in the article according to the interdisciplinary approach.
\end{abstract}

Key word: Mariupol Local Public University; social democratic transformations; educational reform; modern methodological approaches; historical, anthropological, social, cultural and interdisciplinary approaches.

\section{Introduction}

Mariupol has been formed as a Ukrainian polyethnical, border, coastal, industrial town with the influenced intellectuals, educational and culture figures under the influence of several specific factors since its foundation. The dominant democratic, humanistic and tolerant principles were always inherent in the town as well as the local community's desire for educational and culture development despite the long presence of Russian autocracy. The historical experience demonstrated that the desire was realized only under the favorable circumstances in a democratic society. The history of the Mariupol Local Public University (hereinafter MLPU) during 1917-1919 provided convincing evidence to that fact as well as demonstrated the interesting material for the issues of educational, social and political processes consideration at the level of a regional town during the Ukrainian Revolution.

The scientific interest for the phenomenon of Mariupol's history was highlighted only in the post-Soviet period, and only at the beginning of the $21^{\text {st }}$ century. The fact was due to the lack of the MLPU's mentioning by the local Soviet historians during 1920-1980-s as well as the Mariupol's researchers had other study issues during the first Soviet decade.
The interest of the local scientists to the MLPU was drawn only at the beginning of 2000-s. The MLPU's activity was partially presented by the modern Mariupol's historians. The collective work of scientific workers (Bozhko, Buly, Hashenenko, 2006) from The Mariupol Local History Museum presented the short general information regarding the public university.

The Vice Director for scientific work of The Mariupol Local History Museum considered the issues in more detail (Bozhko, 2004; 2020). Analyzing the historical preconditions of the Mariupol State University foundation, V. Romantsov also joined the theme study (Romantsov, 2011; 2013). Nevertheless, the abovementioned studies are conference and journal publications that contain the factual material without any proper analysis and usage of modern methodology.

The purpose of the paper is to highlight the MLPU'S history during 1917-1919-s in the context of the modern methodological approaches.

\section{Methods}

The issue of the educational life in Mariupol during the period of Revolution (1917-1919) requires an application to the modern methodology. The scientific view regarding 
the MLPU' activity implies the implementation of anthropological, social, cultural and interdisciplinary approaches, the direction of microhistory. The works of the Ukrainian and foreign scientists (historians, social scientists, philosophers) contain the theoretical concepts from the mentioned issues.

The theoretical foundations of historical anthropology presented in the works of P. Berk ( 2005), K. Haluschko (2003) and other scientists that analyze a place of historical anthropology in scientific historical studies should be taken into account during highlighting the history of the MLPU. P. Berk (2005) considers historical anthropology in the context of new cultural history and demonstrates a place of man and human communities in the process.

The address to the social and cultural history developed by M. Lapin (2000), T. Parsons (2012), P. Sorokin (1992), facilitates the MLPU's history consideration. T. Parsons claimed that any cultural system could not be institutionalized by itself without integrations with the social environment (Parsons, 2012). That fact is true for the educational activity. Having survived the revolution turmoil in Russia and analyzed its social consequences, $P$. Sorokin wrote: "The whole life cycle of all great revolutions contained... the typical stages. The first is usually short-term. It is referred to the joy of liberation from tyranny of the old regime and promised reforms' anticipation. This initial stage is in radiant mood, the authorities are humanistic and merciful, and the whole policy is of softpower, indecisive and often powerless. However, "the worst beast" has begun to wake up in people. The short overture ends and the second, destructive stage succeeds" (Sorokin, 1992). The evolution is followed on the example of the MLPU. M. Lapin considers social and cultural approach, and social and functional structures ( $\mathrm{La}-$ pin, 2000)

The social and cultural aspects of historical study of Ukrainian province, for instance the regional towns during the Ukrainian revolution were considered by $\mathrm{H}$. BasaraTylischak (2017), O. Rozumna (2014). The views are coordinated with our issue and permit to understand the influence of social processes on the MLPU's activity.

The works devoted to the issues of microhistory usage for the history of the Mariupol Public University consideration have the significant theoretical interest. Ch. Medyk (1994) considered the general bases of microhistory usage and agreed with $\mathrm{G}$. Levi regarding the detailed consideration of a historical object by microhistory in lieu of details study. O. Sachnovskiy (2014) considers microhistory as a direction of historical studies. Ya. Vermenych (2010) analyzes microhistory as a problem area of social and humanistic studies. I. Guseva (2014) highlights the micro aspects of social life and strategies of their development.

The abovementioned complex of the modern methodological approaches guides a researcher to the deep scientific analysis of the issue.

\section{Research and Results}

The period of revolution that launched the democratic transformations in different spheres of social life, initiated the civil activity of thousands of people in March 1917. Mariupol's local community expressed emotional euphoria and desire to realize the plans of educational reform which included the local public university creation that would provide an opportunity for the wide democratic circles of the youth to obtain the modern level of education for affordable fee. That was the way of the European countries as well as the way of the advanced Ukrainian and Russian public.

ISSN 1728-9343 (Print)

ISSN 2411-3093 (Online)
The history of the MLPU was brief; however, it was an interesting and bright page of Mariupol. The yellowed pages of Mariupol's newspapers 100-year -old contain the records that reveal the great interest to the educational institution's activity and have left the great informational massive for the scientists of future generations regarding the issue.

The members of literature and scientific circle had borne the thought about the MLPU foundation for a year, since 1916. The representatives of Mariupol's democratic intellectuals dreamt "to lead the educational work among the locals and to pure the bright thought in absolute mist of the old regime". The literature and scientific circle created a committee of public education, the members of which worked under the issue of public university's creation in 1916. Nevertheless, after a year they had to state that "all desires and attempts to initiate public lectures were halted by all possible means by the administration of the police authorities at the beginning". Only the February Revolution brought "the days of liberty and individual emancipation" " was mentioned in a memorandum from the public education committee.

An initiative of the MLPU foundation came from Mariupol's democratic public that increased its activity in various communities after the overthrow of Russian autocracy. The board meeting of literature and scientific circle, where all practical questions regarding the MLPU were solved, was on March 19, 1917. L. Gintston was elected as a head of the office of the circle that acted under the democratic transformations; S. Vainerova was elected as a deputy and I. Aluf - as a secretary ${ }^{2}$. S. Vainerova initiated the further practical activity regarding public university's foundation.

After organizational issues' discussion, S. Vainerova presented her report in which offered a project of public university's foundation. It was meticulously discussed and some changes were amended. The circle board encouraged support of the university's foundation from the commission elected by the Mariupol local public executive committee (hereinafter MLPEC) and all local educational communities. All offered propositions regarding the issue were decided to approve at the general meeting of literature and scientific circle on March, $23^{3}$.

The first donations to the MLPU were performed at the meeting on March, 19. The contributors were L. Gintston and S. Vainerova and donation was 10 and 20 rubles respectively ${ }^{4}$. The further charity events were in April, May, June and till August, 10 thou. rubles were collected (Bozhko, 2020).

The preparation work was performed by the commission of public education of the MLPEC in the following period till October 1917. It was coordinated by the work of Literature and Scientific Circle, Pedagogical Committee, Students' Circle, Women's Union, Council of Workers' and Solders' Deputies that were interested in the issue. The records about the Moscow public university named after A. Schaniavskyi and the public university of Nizhny Novgorod ${ }^{5}$ were used in the preparatory work. The com-

\footnotetext{
${ }^{1}$ Мариупольское слово (The Mariupol Word). October 29, 1917.

2 Мариупольская жизнь (The Mariupol Life). March 23, 1917.

${ }^{3}$ Мариупольская жизнь. (The Mariupol Life). March 23, 1917.

${ }^{4}$ Мариупольская жизнь. (The Mariupol Life). March 23, 1917.

${ }^{5}$ Мариупольское слово (The Mariupol Word). October 29, 1917.
}

SKHID No. 4 (168) July-August 2020 
mission member of public education of the MLPEC I. Kovalenko was familiar with the working of the Moscow public university named after A. Schaniavskyi, as he used to be a student at the educational institution (Bozhko, 2020).

On August $17^{\text {th }}$ the City Council of Mariupol unanimously accepted a project of the MLPU foundation ${ }^{6}$. The commission member of public education of the MLPEC I. Kovalenko, the member of public executive committee ensign of $24^{\text {th }}$ reserve Infantry Regiment M. Druzynin, the head of the Council of Workers' and Solders' Deputies Ya. Koval spoke when the issue was discussed at the meeting of the City Council ${ }^{7}$.

The official opening of the MLPU was on October 29, 1917. It was turbulent time for the whole country in general and for Mariupol's community in particular. The Bolshevik coup took place in Petrograd that opened "Pandora's box" of communistic dictatorship. Mariupol was concerned about the events, waited for the news from Russian capital where all power was seized by the political extremists. Fortunately for the Mariupol's citizens, the democratic institutions of the local authorities (the City Council) had more support from the society in a town than the Bolsheviks, hence, the town continued to live under the circumstances of democratic process. The local authorities mentioned in their appeal to the citizens: "Russia has again survived a crisis of power! The presence of mind and absolute peace should be kept during the days

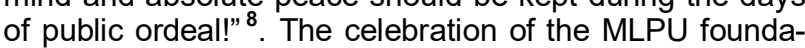
tion occurred in the political situation of social peace in Mariupol. The event was described in detail by the newspaper "The Mariupol Word" that reflected the great social interest to the new public university from the citizens.

It was mentioned in a report of a commission of public education of the MLPEC that "the public university aims at the wide democratic mass attraction to science and knowledge as well as the widespread of scientific education among population". According to the plan of the founders, the university should provide an opportunity to obtain "general knowledge as well as the high education accessible for all wide layers of the society". The departments of general knowledge were anticipated to be created together with the departments of special technical knowledge as well as the departments of "national culture issues should be organized depends on the wishes and necessities of citizens" 9 .

The programs of learning subjects were targeted to four years according to daily evening classes of two hours. The students should learn the general subjects for the first two years and special subjects - for the last two years. The students had chosen any particular direction (history, natural science, political economy, statistics, etc.) for learning and learnt it during the whole period of study ${ }^{10}$

The Mariupol Local Public University was under the rule of the Mariupol Local Public Self-government and expanded its activity on a town and region. The financial resources were supposed to obtain from the local, governmental, public institutions, donations and tuition fees.

\footnotetext{
${ }_{7}^{6}$ Наше життя (Our Life). May 30 (17), 1918.

7 Мариупольское слово (The Mariupol Word). August 19, 1917.

${ }^{8}$ Мариупольское слово (The Mariupol Word). October 29, 1917.

${ }^{9}$ Мариупольское слово (The Mariupol Word). October 29, 1917.

${ }^{10}$ Мариупольское слово (The Mariupol Word). October 29, 1917.
}

The board of trustees performed university's management $^{11}$

The donations amounting to approximately 6800 rubles were made on the day of university's official opening, on October 29, $1917^{12}$. Approximately 200 students entered the university at natural science and social studies departments. The classes began on November 1, 1917. The class schedule contained the following subjects: Russian language and literature, history, psychology, national economy, law at the department of social studies and Russian language, arithmetic, geometry, physics, geography, zoology, botanic, microbiology at the department of natural science. The famous Mariupol's lecturers were invited to provide lectures: A. Aleksandrovych, M. Chmelnytskyi, V. Kochergin, D. Kononovych, K. Lubymova, M. Protopopov, V. Rudevych, O. Snovedskyi, S. Vainerova and others ${ }^{13}$.

The renewed Ukrainian statehood spread the power in Mariupol shortly after the acceptance of the Third Universal of the Ukrainian Central Council that proclaimed the Ukrainian People's Republic. The MLPU continued to work without any political barriers under the new social and political circumstances. Nevertheless, the further political changes caused by the power armed seizure of Mariupol's Bolsheviks in a town on December 30, 1917 (Bozhko, 2020; Bozhko, Buly, Hashenenko, 2006), strengthened military and political confrontation in a region as well as in a country. It opened a way for the constant change of the authorities in a town that negatively influenced on the activity of the educational institutions, including the MLPU.

In May 1918 the head of the Board of trustees of the MLPU S. Vainerova mentioned: "The public university has survived a tough year. Nevertheless, the classes were and students visited the classes attracted by knowledge thirsty". However, the financial resources collected for the university had been exhausted. As the Local Council did not have an opportunity to provide financial help to the MLPU, the head of the Board of trustees applied to the Local Government with the request to give 4 thou rubles to a university treasurer for salaries' payment for the employees $^{14}$.

The public university encountered the serious financial problems under the circumstances of crisis escalation during 1918. "The community for collecting donations" was created in autumn. The community's founders were the authoritative citizens V. Ostroslavska, A. Pasternak, G. Psalti, P. Roskoschynskyi, V. Rudevych, B. Vainerova, S. Vainerova, M. Zemtsov ${ }^{15}$.

The community donated 1500 rubles as one-time assistance to a food committee in 1918. Still, it was not possible to cover all urgent payments ${ }^{16}$. The MLPU organized a charity performance for collecting donations for the public university on January $1,1919^{17}$. The Board of

\footnotetext{
${ }^{11}$ Мариупольское слово (The Mariupol Word). October 29, 1917.

${ }_{12}$ Мариупольское слово (The Mariupol Word). November 14, 1917.

${ }_{13}$ Мариупольское слово (The Mariupol Word). November 14, 1917.

${ }^{14}$ Наше життя (Our Life). May 30 (17), 1918

${ }^{15}$ Мариупольский вестник (The Mariupol Bulletin). October 18, 1918.

${ }^{16}$ Мариупольские известия (The Mariupol News). January 3. 1919

${ }^{17}$ Мариупольские известия (The Mariupol News). January 14 (1), 1919.
} 
trustees of the MLPU considered the issue of funds allocation by the Board of Mariupol tenants' community in the amount of 100 rubles for the university and decided to "express deep gratitude to the community for their attention to public educational activity" at the meeting on January $13(26)^{18}$

The second academic year began at the MLPU on October 4, 1918. The teacher of the high commercial courses in Petrograd M. Kechedzy-Schapovalov was invited as a lecturer for cooperation study ${ }^{19}$. The shortage of the educational staff had worsened at the MLPU at the beginning of 1919. The Board of trustees announced about an open vacancy of a literature lecturer ${ }^{20}$ and $a$ lecturer of political economy ${ }^{21}$.

The third academic year began at the MLPU on November 4, 1919. There were two departments at the university: preparatory and academic. The first department was aimed at enhance and systematized knowledge, spatially for those students who obtained primary or home education. There were lectures of Russian language, arithmetic, history, geography and natural science. Only 15 men entered the preparatory department.

The academic department was aimed at expanding knowledge of the students who had already had the solid knowledge base and had known Russian language grammar, arithmetic, history, geography and natural science. There were lectures of literature, Russian and World history, geography, physics, chemistry, geometry, algebra, zoology, botanic and physical geography. There were only 39 men at the department. It was planned that the lectures on the program were accompanied by feebased lectures on literature, astronomy, history, political economy ${ }^{22}$.

The absence of historical sources does not permit to follow the further fate of the MLPU. We can agree with P. Bozko who has mentioned 1919 as the final date of the university existence in her last publication (Bozhko, 2020), as she is well aware of the materials from the Mariupol Local History Museum. We can only make some assumptions about the university's work termination. Mariupol was under the circumstances of constant turmoil when the authorities were changed by the violent means at least 15 times (according to the authors' calculations) during 1917-1919-s. The town was in a war zone, and was frequently seized by the hostile military forces. The quantity of local citizens had dramatically decreased; economic activity and financial viability of the citizens was ruined. The abovementioned factors caused a crisis of Mariupol educational institutions and it had especially negative impact on the MLPU's activity as it had worked only for two years and was depended on the local authorities' financing, donations and educational fees. All financial resources had been exhausted at the end of 1919. It was impossible to exist for the educational institution. The Ukrainian Revolution had failed, and the authorities of Bolsheviks, which eventually came in 1920, were not interested in the MLPU's activity.

\footnotetext{
${ }^{18}$ Мариупольские известия (The Mariupol News). February 20 (7), 1919.

${ }_{19}$ Мариупольский вестник (The Mariupol Bulletin). October 18, 1918.

${ }^{20}$ Мариупольские известия (The Mariupol News). January 29 (16), 1919.

${ }^{21}$ Мариупольские известия (The Mariupol News). February 2 (January 20), 1919.

${ }_{22}$ Мариупольские новости (The Mariupol News). November 24, 1919.
}

\section{Conclusions}

The short-term history of the MLPU is a bright example of social processes' impact on the educational activity. The public university was the first attempt of a high educational institution's creation in the history of Mariupol. An idea of its foundation was implemented under the circumstances of democratic transformations in Mariupol and was an embodiment of local community's desire to improve intellectual field in the town. Such social and cultural factor played a crucial role under the circumstances when the society wished democratic changes. The MLPU was established with the aid of Mariupol's intellectuals, local democratic representatives who endeavored to diversify the educational possibilities and make them more accessible for the youth from low and middle income families.

The history of the MLPU's activity demonstrated that the Democratic Revolution of 1917 and implemented transformations created the favorable conditions for the public university. Nevertheless, the Bolshevik military coup destroyed democratic process and became a starting point to the attack of radical social forces and to the further bloody confrontations. It negated all attempts aimed at enhancement of educational possibilities. It is proved by the studies of the issue in the context of historical, anthropological, social, cultural and interdisciplinary approaches and "the problem field" of microhistory in "the socio-humanitarian studies".

The experience of the MLPU is crucial as it testifies the important connection between the local educational initiatives and general governmental policy. The Mariupol Local Public University (1917-1919) was a predecessor of the Mariupol State University. Both appeared under the circumstances of social life democratization and reflected the desire of the Mariupol local community to expand the sphere of humanistic education. Nevertheless, the activity of the first university was halted due to the military actions during 1919-1920-s and the Bolshevik authorities' rejection of democratic transformations. The modern Mariupol State University has an opportunity to accept successfully the challenges with the assistance of the Ukrainian State and foreign partners despite economic problems and grueling liberation war of Ukraine.

\section{REFERENCES}

Basara-Tylishchak, H. (2017). Vid provintsiynoyi hlybynky do revolyutsiynoho tsentru: politychni ta sotsiokulturni aspekty rozhortannya Ukrayinskoyi revolyutsiyi v povitovykh mistakh. Revolyutsiya, derzhavnist, natsiya: Ukrayina na shlyakhu samostverdzhennya (1917-1921 rr.): Proceedings of the International Scientific Conference. Kyiv, June 1-2, 2017. KyivChernihiv: Siverskyy tsentr pislyadyplomnoyi osvity, P. 510524 (In Ukrainian).

Berk, P. (2005). Istorycheskaya antropolohyya i novaya kulturnaya istoriya. Retrieved from https://magazines.gorky.media/nlo/2005/5/istoricheskaya-antropologiya-i-novayakulturnaya-istoriya.html (In Russian)

Bozhko, R. (2004). Pervyy narodnyi universitet. llyichevets. 06.08, S.4. (In Russian)

Bozhko, R. (2020). Mariupolskyi miskyi narodnyi universytet chasiv Ukrayinskoyi revolyutsiyi. Forum krayeznavtsiv Donechchyny. Dopovidi uchasnykiv. Vinnytsya-Slovyansk: Vasul Stus Donetsk National University, pp. 115-117 (In Ukrainian)

Bozhko, R., Buly, T., Hashenenko, N. (2006). Mariupol $i$ ego okrestnosti: vzhliad iz XXI veka. Maryupol: Renata, 356 p. (In Russian)

Halushko, K. Yu. (2003). Antropolohiya istorychna Entsyklopediya istoriyi Ukrayiny: u 10 t. Kyiv: Naukova dumka, Vol. 1: A - V. P. 109. (In Ukrainian) 
Guseva, I. I. (2014). Mykrorakursy sotsyalnoho i stratehii ikh issledovaniya. Izvestiya Saratovskogo universiteta. Seriya: Filosofiya. Psykhologiya. Pedagogika. 14 (2): 15-20 (In Russian)

Lapin, N. I. (2000). Sotsyokulturnyy podkhod i sotsietalnofunktsyonalnyie struktury. Sotsiologicheskie Issledovaniia. 7: 3-12. Retrieved from https://www.isras.ru/files/File/Socis/072000/001.LAPIN.pdf (In Russian)

Medyk, Kh. (1994). Mikroistoriya. THESIS, 4: 193-202. (In Russian)

Parsons, T. (2012). Sistema sovremennykh obshchestv. Tsentr humanytarnykh tekhnolohii. 09.09.2012. Retrieved from https://gtmarket.ru/laboratory/basis/5395 (In Russian)

Romantsov, V. (2013). U istokov razvitiya vyssheho obrazovaniya v Mariupole. Mariupolskii horodskoy narodnyi universytet. Pryazovskii rabochii. 2013.05.08 (In Russian)
Romantsov, V. (2011). Mariupolskyo miskyy narodnyy universytet. Istorychni vytoky MDU. Nauka ta osvita $v$ suchasnomu universyteti $v$ konteksti mizhnarodnoho spivrobitnytstva. Proceeding Paper (May, 23-25, 2011). Mariupol, 2011. Pp. 135136 (In Ukrainian)

Rozumna, O. (2014). Ukrayinska provintsiya yak sotsiokulturnyy fenomen. Stratehichni priorytety, 1 (30): 135-140 (In Ukrainian)

Sachnovskiy, O. (2014). Mikroistoriya yak napryam istorychnykh doslidzhen. Istorychna panorama. 18: 65-78 (In Ukrainian)

Sorokin, P. (1992). Chelovek, tsyvilizatsyya, obshchestvo. Moskva: Polytyzdat.

Vermenych, Ya. V. (2010). Mikroistoriya yak problemne pole sotsiohumanitarnykh doslidzhen. Ukrainskyi Istorychnyi Zhurnal. 4: 156-169. Retrieved from http://resource.history.org.ua/publ/journal 20104156 (In Ukrainian)

Володимир Романцов,

Маріупольський державний університет (м. Маріуполь, Украӥна)

e-mail: romantsov_v@ukr.net

Наталя Романцова,

Маріупольський державний університет (м. Маріуполь, Украӥна)

e-mail: romantsov_v@ukr.net

\section{МАРІУПОЛЬСЬКИЙ МІСЬКИЙ НАРОДНИЙ УНІВЕРСИТЕТ 1917-1919 рр.: НАРИС ІСТОРІЇУ КОНТЕКСТІ СУЧАСНИХ МЕТОДОЛОГІЧНИХ ПІДХОДІВ}

У статті на засадах сучасних методологічних підходів висвітлюється питання щодо створення та діяльності Маріупольського міського народного університету у суспільних процесах Української революції протягом 1917-1919 рр. Історія зазначеного закладу освіти аналізується в контексті антропологічного, соціокультурного, міждисциплінарного підходів. Відповідно до методологічних принципів мікроісторії детально розглядаються питання про організацію Маріупольського міського народного університету, принципи його функціонування. Висвітлюється освітня діяльність університету, його викладацький склад, контингент слухачів. Відповідно до методологічних принципів соціокультурної історії акцентується увага на активній організуючій діяльності маріупольської демократичної громадськості того часу у справі заснування університету, на впливі мінливих суспільних процесів, які відбувалися загалом в Україні, зокрема в Маріуполі щодо вирішення зазначених освітніх питань. На методологічних засадах історичної антропології розглядається роль окремих історичних персонажів освітнього, громадського життя міста (голови опікунської ради народного університету С. Вайнерової, голів Маріупольської міської думи І. Попова, О. Левицького, члена комісії Маріупольського громадського виконавчого комітету 3 народної освіти І. Коваленка та інших). Згідно 3 міждисциплінарним підходом у статті поєднані елементи історії, соціології та культурології.

Ключові слова: Маріупольський міський народний університет; суспільні демократичні перетворення; освітня реформа; сучасні методологічні підходи; історико-антропологічний; соціокультурний; міждисциплінарний підходи.

(C) Volodymyr Romantsov, Natalia Romantsova

Надійшла до редакції: 13.07.2020

Прийнята до друку: 07.08.2020 